\title{
GAYA BAHASA SINDIRAN PADA LIRIK LAGU DALAM ALBUM FREKUENSI PERANGKAP TIKUS VOLUME DUA DAN IMPLIKASINYA TERHADAP PEMBELAJARAN BAHASA DAN SASTRA INDONESIA
}

\author{
Ainiyah Ekowati ${ }^{\left.\mathrm{a}^{*}\right)}$, Stela Talitha ${ }^{\text {a) }}$, Rima Rosita ${ }^{\text {a) }}$ \\ a) Universitas Pakuan, Kota Bogor, Indonesia \\ *) e-mail korespondensi: ainiyahekowati86@gmail.com
}

\section{Riwayat Artikel}

diterima 15 November 2021 direvisi 29 November 2021 disetujui 30 Desember 2021

\begin{abstract}
Abstrak.
Gaya bahasa sindiran adalah salah satu jenis gaya bahasa yang digunakan seseorang untuk mengejek secara tidak langsung. Pada gaya bahasasindiran terdapat tiga jenis di dalamnya. Penelitian ini mengkaji mengenai Gaya Bahasa Sindiran pada Lirik Lagu dalam Album Frekuensi Perangkap Tikus Volume Dua dan Implikasinya terhadap Pembelajaran Bahasa Indonesia di SMA. Fokus permasalahan ini adalah penggunaan gaya bahasa sindiran pada lirik lagu dalam album Frekuensi Perangkap Tikus Volume Dua dan subfokus penelitian ini adalah Implikasi gaya bahasa sindiran pada lirik lagu dalam album Frekuensi Perangkap Tikus Volume Dua terhadap pembelajaran bahasa Indonesia di SMA. Penelitian ini bertujuan untuk mendeskripsikan penggunaan gaya bahasa sindiran pada lirik lagu dalam album Frekuensi Perangkap Tikus Volume Dua. Metode yang digunakan, yaitu yaitu metode deskriptif kualitatif, artinya hasil penelitian akan dipaparkan berupa kata-kata dari beberapa temuan data yang telah diolah. Dari hasil analisis tersebut ditemukan 52 data, yang terdiri dari 4 sindiran jenis ironi, 11 sindiran jenis sarkasme, dan 37 sindiran jenis sinisme. Album Frekuensi Perangkap Tikus Volume Dua ini, dapat dijadikan bahan pembelajaran Bahasa Indonesia bagi siswa di SMA
\end{abstract}

Kata Kunci: Gaya Bahasa Sindiran, Album Frekuensi Perangkap Tikus Volume Dua, Lirik Lagu.

\section{SATIRE LANGUAGE STYLE IN SONG LYRICS IN THE SECOND VOLUME RAT TRAPPING FREQUENCY ALBUM AND ITS IMPLICATIONS FOR LEARNING INDONESIAN LANGUAGE AND LITERATURE}

Abstract. Satire language style is one type of language style used by someone to mock indirectly. In the style of satire, there are three types in it. This study examines the Satire Language Style in Song Lyrics in the Volume Two Mouse Trap Frequency Album and its implications for Indonesian language learning in high school. The focus of this problem is the use of satire language style in song lyrics in the album Frequency of Mouse Trap Volume Two and the subfocus of this research is the implication of satire language style on song lyrics in the album Frequency of Mouse Trap Volume Two on Indonesian language learning in high school. This study aims to describe the use of satire language style in song lyrics in the album Frequency of Trap Rats Volume Two. The method used is descriptive qualitative method, meaning that the research results will be presented in the form of words from several data findings that have been processed. From the results of the analysis found 52 data, consisting of 4 types of irony satire, 11 satire types of sarcasm, and 37 satire types of cynicism. This Volume Two Mouse Trap Frequency Album can be used as Indonesian language learning material for high school students.

Keywords: Satire Language Style, Mouse Trap Frequency Album Volume Two, Song Lyrics.

\section{PENDAHULUAN}

Sastra Indonesia tumbuh dan berkembang dari budaya Indonesia yang beraneka ragam. Sastra dapat diciptakan oleh siapa saja.Suatu karya dapat dikatakan memiliki nilai sastra bila di dalamnya terdapat kesepadanan antara bentuk dan isi.Bentuk bahasanya baik, indah, danisinya dapat menimbulkan kekaguman di hati pembaca, sehingga pembaca bersemangat dan tertarik untuk membacanya.

Dari dulu hingga sekarang, karya sastra tidak pernah pudar dan mati, kenyataannya karya sastra dapat mengembangkan wawasan berpikir bangsa. Dalam proses menyelami makna dari karya sastra, otak kita dilatih untuk aktif memberikan interpretasi, sehingga secara tidak sadar, karya sastra memiliki peran untuk melatih sikap kritis seseorang dan memiiki kepekaan yang tinggi, hal ini bisa dilihat dari karya-karya sastra yang sering kali mengangkat isu tentang kemanusiaan, global, dan lingkungan. Sebagai penerus bangsa sastra harus dilestarikan dan dikembangkan.

Dalam kehidupan sehari-hari hampir semua aktivitas masyarakat menggunakan bahasa, baik berbahasa secara lisan maupun tulis. Begitu dekatnya kita dengan bahasa, terutama bahasa Indonesia, sebagai bahasa nasional untuk persatuan bangsa.Bahasa Indonesia adalah satu-satunya alat yang memungkinkan kita membina dan mengembangkan kebudayaan nasional.Bahasa merupakan faktor pendukung sebagai penguat jati diri bangsa. Rasa kebanggaan memiliki bahasa Indonesia terikat erat dengan pencerminan cinta tanah air. Harmonisasi interaksi masyarakat Indonesia dapat dibina melalui bahasa Indonesia.Sebagai generasi bangsa 
sudah menjadi kewajiban untuk menjunjung tinggi budaya dan bahasanya.

Bahasa mempunyai peran penting di dalam kehidupan manusia. Melalui bahasa, manusia dapat berinteraksi, berkomunikasi, dan mengembangkan dirinya.Bahasa juga berperan penting dalam pendidikan, bahasa dapat membentuk karakter manusia. Baik buruknya karakter seseorang tercermin dari cara orang tersebut ketika berbahasa. Pada dasarnya bahasa memiliki fungsi-fungsi tertentu yang digunakan berdasarkan kebutuhan seseorang, yakni sebagai alat untuk mengekspresikan diri, sebagai alat untuk berkomunikasi, dan beradaptasi sosial dalam lingkungan atau situasi tertentu.

Dari berbagai fungsi bahasa tersebut, dalam penggunaan bahasa sehari-hari biasanya seseorang menggunakan gaya bahasa yang merupakan salah satu alat komunikasi baik secara lisan maupun tulisan. Gaya bahasa adalah penggunaan kata-kata dan kalimat-kalimat oleh penulis atau pembicara dalam mengekspresikan ide, gagasan, dan pengalamannya untuk mempengaruhi pembaca atau pendengar. Gaya bahasa memiliki bermacam-macam jenis, yang terdiri dari gaya bahasa perbandingan, gaya bahasa pertentangan, gaya bahasa pertautan, gaya bahasa perulangan, dan gaya bahasa sindiran.

Gaya bahasa perbandingan meliputi gaya bahasa metafora, simile, personifikasi, alegori, dan antitetis. Gaya bahasa pertentangan meliputi gaya bahasa hiperbola, litotes, oksimoron, paronomasia, paralipsis, dan zeugma. Gaya bahasa pertautan meliputi gaya bahasa metonimia, sinekdoke, alusi, eufimisme, dan elipsis. Gaya bahasa perulangan meliputi gaya bahasa aliterasi, antanaklasis, kiasmus, dan repetisi. Gaya bahasa sindiran meliputi gaya bahasa ironi, sinisme, dan sarkasme.

Macam-macam gaya bahasa banyak kita temui di dalam kehidupan sehari-hari, contohnya dalam lirik lagu, puisi, novel, dan sebagainya. Gaya bahasa bisa digunakan seseorang untuk mengungkapkan arti yang bukan sebenarnya melalui sindiran halus maupun kasar. Dengan begitu, pembaca tidak bosan dan semakin tertarik untuk membaca sebuah karya sastra.Permasalahannya saat ini tidak semua orang yang menerima pesan mengerti makna dari pesan yang sesungguhnya. Pemahaman yang kurang tepat pada makna yang disampaikan dapat menimbulkan salah pengertian, untuk itu kita harus memperhatikan ciri-ciri pada setiap gaya bahasa.

Gaya bahasa sindiran merupakan salah satu jenis gaya bahasa yang biasa digunakan seseorang untuk mengutarakan sesuatu dengan maksud menyindir, mencela, atau mengejek secara tidak langsung. Gaya bahasa sindiran dibedakan menjadi tiga macam, yaitu gaya bahasa ironi, sinisme, dan sarkasme. Ketiga macam gaya bahasa sindiran tersebut memilki arti yang berbeda, gaya bahasa ironi merupakan gaya bahasa yang menyindir secara halus, ironi mengimplikasikan sesuatu yang nyata berbeda, bahkan bertentangan dengan yang dikatakan. Gaya bahasa sinisme berupa sindiran berbentuk kesangsian yang mengandung ejekan, dan yang terakhir yaitu gaya bahasa sarkasme adalah gaya bahasa yang menyindir secara pedas dan bisa menyakiti hati seseorang.

Sebagian pengarang menggunakan macam-macam gaya bahasa sindiran tersebut dalam lirik lagu yang ingin disampaikan kepada penikmatnya dalam tujuan tertentu. Gaya bahasa yang dimiliki setiap pengarang mempunyai ciri khas masing-masing dalam menyampaikan karyanya. Lagu dapat didefinisikan sebagai ragam suara yang di dalamnya terdapat lirik-lirik bernada.Awalnya lagu hanya dipergunakan sebagai media hiburan saja, pada perkembangannya lagu juga kerap digunakan sebagai media pembelajaran dalam dunia pendidikan untuk menanamkan nilai moral seseorang.

Gaya bahasa pada lagu tentu berbeda dengan gaya bahasa pada sastra lainnya, karena dalam lagu diungkapkan dengan nada-nada yang indah, pendengar atau pembaca bisa ikut merasakan susasana dalam lirik lagu tersebut. Album Frekuensi Perangkap Tikus Volume Dua terdapat lirik yang memperlihatkan bagaimana cara bertutur mengenai korupsi dengan menggunakan gaya bahasa, yaitu gaya bahasa sindiran.

Gaya bahasa dapat dilihat dari penggunaan kata dalam lirik yang dituliskan seseorang dalam mengungkapkan sesuatu dengan bahasa yang indah. Seseorang dapat menemukan berbagai macam gaya bahasa, baik lisan maupun tulisan dalam berinteraksi di kalangan masyarakat. Dalam pengamatan peneliti, banyak menemukan gaya bahasa yang digunakan oleh beberapa musisi, musisi-musisi tersebut menyumbang lagu mengusung gerakan pemberantas korupsi dan berfokus pada kesadaran antikorupsi.

Pemberantasan korupsi bisa dilakukan oleh semua orang, oleh karena itu Indonesian Corruption Watch (ICW) melakukan kampanye antikorupsi dengan merilis album Frekuensi Perangkap Tikus Volume Dua, album ini lebih mengedepankan propaganda perlawanan terhadap korupsi dengan cara yang lebih halus dan sederhana. Lagu-lagu yang disumbangkan dalam album ini memuat materi yang lebih menyentuh kehidupan keseharian masyarakat. Karena lagu adalah media yang paling mudah untuk penyampaian pesan, maka makna yang terkandung dalam album Frekuensi Perangkap Tikus Volume Dua bisa dicerna langsung oleh masyarakat Indonesia.

Oleh karena itu, peneliti akan melakukan penelitian dengan judul "Analisis Gaya Bahasa Sindiran pada Lirik Lagu dalam Album Frekuensi Perangkap Tikus Volume Dua dan Implikasinya terhadap Pembelajaran Bahasa Indonesia di SMA".

\section{METODOLOGI PENELITIAN}

\section{A. Metode Penelitian}

Metode yang digunakan dalam penelitian ini adalah metode deskriptif kualitatif. Sugiono (2018:1) mendefinisikan bahwa metode penelitian pada dasarnya merupakan cara ilmiah untuk mendapatkan data dengan tujuan kegunaan tertentu. Moleong (2007:6) mendefinisikan bahwa penelitian kualitatif adalah penelitian yang menghasilkan prosedur analisis statistik atau cara kuantifikasi lainnya. Sedangkan deskriptif data yang 
disampaikan adalah berupa kata-kata, gambar, sehingga tidak menekankan pada angka. Hal itu disebabkan oleh adanya penerapan metode kualitatif. Selain itu semua yang dikumpulkan berkemungkinan menjadi kunci terhadap apa yang diteliti.

\section{B. Data dan Sumber Data}

Berdasarkan variabel penelitian, data yang digunakan dalam penelitian yaitu, berupa kutipan kalimat yang mengandung gaya bahasa sindiran pada kumpulan lirik lagu dalam album Frekuensi Perangkap Tikus Volume Dua.

Sumber data penelitian ini adalah kumpulan lirik lagu dalam album Frekuensi Perangkap Tikus Volume Dua, yang terdiri dari sembilan judul lagu dengan penyanyi yang berbeda.

\section{Pengumpulan Data}

Teknik pengumpulan data yang digunakan yaitu teknik dokumen. Teknik dokumen, yaitu teknik mencari data mengenai hal-hal yang valid. Studi dokumen atau teks merupakan jenis penelitian kualitatif yang berbasis pada dokumen. Dokumen yang dimaksud dalam penelitian ini adalah lirik lagu, pada tahap ini akan dikumpulkan dan dianalisis seluruh data yang berhubungan dengan gaya bahasa sindiran pada lirik lagu dalam album Frekuensi Perangkap Tikus Volume Dua.

\section{Pengecekan Keabsahan Data}

Kesesuaian teori dan hasil penelitian merupakan hal yang harus dipenuhi untuk mencapai kesempurnaan hasil penelitian. Oleh karena itu, penulis melakukan pengujian terhadap keabsahan data yang diteliti. Penelitian ini menggunakan tringulasi sumber untuk menguji keabsahan data.

Keabsahan data perlu dilakukan untuk mengetahui kebenaran data. Dalam menguji keabsahan data, penulis menunjuk triangulator untuk memberikan pernyataan terhadap temuan data yang penulis dapatkan sebagai langkah pengecekan kembali data-data yang diperoleh dari informan yang satu dengan informan yang lainnya. Triangulasi adalah teknik pemeriksaan keabsahan data yang memanfaatkan sesuatu yang lain (Moeleong, 2007:330).

\section{E. Analisis Data}

Setelah mengumpulkan data berupa lirik lagu, langkah selanjutnya adalah analisis data. Penulis menggunakan analisis data kualitatif untuk menganalisis gaya bahasa sindiran pada lirik lagu dalam album Frekuensi Perangkap Tikus Volume Dua.

\section{HASIL PENELITIAN DAN PEMBAHASAN}

\section{A. Deskripsi}

Pada bab ini akan diuraikan tentang gaya gahasa sindiran yang terdapat pada kumpulan lirik lagu dalam album Frekuensi Perangkap Tikus Volume Dua.Peneliti menguraikan hasil penelitian dengan mendeskripsikan data. Hal ini bertujuan untuk memberikan data objektif tentang penelitian agar peneliti lebih terarah dalam melakukan analisis. Data yang ditemukan, yaitu berupa kutipan lirik lagu yang mengandung gaya bahasa sindiran dalam album Frekuensi Perangkap Tikus Volume Dua.

\section{B. Temuan Penelitian}

Dari hasil analisis tersebut ditemukan 52 data, yang terdiri dari 4 sindiran jenis ironi, 11 sindiran jenis sarkasme, dan 37 sindiran jenis sinisme.

\section{Pembahasan Temuan}

Pembahasan temuan ini digunakan untuk mendeskripsikan mengenai gaya bahasa sindiran yang terdapat pada album Frekuensi Perangkap Tikus Volume Dua dalam bentuk analisis.

Judul Lagu : : Lapang

Data Kutipan : Mengawali hari yang penuh jenuh

Besar rasa penat

yang diserap dalam sukma

Yang kerap terusik

dengan tilikan harian

Pada kutipan lirik lagu di atas terdapat kalimat "Mengawali hari yang penuh jenuh" dapat diidentifikasi adanya gaya bahasa sindiran jenis sinisme, majas sindiran merupakan kelompok majas yang mengungkapkan maksud atau gagasan dengan cara menyindir seseorang guna meningkatkan kesan dan makna kata terhadap pembaca secara lisan maupun tulisan. Sindiran sering muncul sebagai pengingat bagi seseorang yang sering berperilaku berlebih. Sindiran jenis sinisme ditandai kalimat "hari yang penuh jenuh" menunjukan adanya pandangan seseorang yang mengandung ejekan terhadap keikhlasan suatu hal dengan mengungkapkan kalimat terang-terangan. Majas sinisme merupakan gaya bahasa yang menyindir dan tidak menggunakan ungkapan lain. Sindiran jenis sinime ini lebih keras atau kasar daripada sindiran jenis ironi serta sinisme mengandung kata-kata atau kalimat-kalimat faktual dengan apa yang terjadi. Secara langsung gaya bahasa sinisme terjadi diungkapkan dengan memberikan gambaran yang didukung kata "jenuh" tersebut.

Dalam kutipan kalimat tersebut, kata "jenuh" dalam Kamus Besar Bahasa Indonesia merupakan sifat bosan dan kadang hal ini membuat sebagian orang menjadi malas.Makna dari kalimat tersebut, yaitu seseorang jenuh untuk mengawali hari yang penuh sandiwara kebohongan.Kutipan lirik lagu tersebut bertujuan untuk menyindir mereka yang telah bermain kotor di belakang rakyat biasa.Sejalan dengan judul lagu tersebut yaitu "Lapang", seseorang tersebut berusaha menerima perlakuan mereka dengan seenaknya mengambil uang rakyat tanpa memperdulikan akibat yang telah merugikan banyak orang.

Dengan demikian kalimat "Mengawali hari yang penuh jenuh" dalam judul lagu "Lapang" jelas memberikan makna sindiran jenis sinisme karena mengandung adanya ejekan terhadap keikhlasan suatu hal secara terang-terangan, sehingga memberikan pernyataan atau situasi yang bermaksud untuk menyindir. Gaya bahasa sindiran jenis sinisme merupakan gaya bahasa menyindir secara terangterangan dan tidak menggunakan ungkapan lain. Sindiran jenis sinime ini lebih keras atau kasar daripada sindiran jenis 
ironi serta sinisme mengandung kata-kata atau kalimatkalimat secara faktual dengan apa yang terjadi.

\section{Interpretasi Data}

Dari kumpulan lirik lagu dalam album Frekuensi Perangkap Tikus Volume Dua terdapat penggunaan gaya bahasa sindiran, di antaranya:

Ironi

Sindiran jenis ironi menunjukkan adanya praktik kepura-puraan karena menyembunyikan makna yang sebenarnya dengan maksud menyindir secara halus, walaupun terdengar halus tetapi sebenarnya memiliki maksud kasaragar lawan bicara tidak menanggapi dengan emosi yang berlebihan, salah satu contoh lirik lagudalam album Frekuensi Perangkap Tikus Volume Dua ditandai kalimat "merobek topeng-topeng manis"kata "topeng manis" merupakan suatu hal yang bertentangan dengan makna sesungguhnya bisa diartikan sebagai orang bermuka dua karena kebohongan dan kecurangan yang diperbuat oleh mereka yang bermuka dua seperti berpura-pura baik kepada masyarakat, tetapi faktanya telah menyengsarakan masyrakat.

Sinisme

Sindiran jenis sinisme mengandung adanya ejekan terhadap perilaku buruk seseorang yang telah dilakukannya, sinisme bertujuan untuk menyinggung dan menyindir seseorang secara terang-terangan, salah satu contoh lirik lagudalam album Frekuensi Perangkap Tikus Volume Dua ditandai kalimat"Korupsi uang jadinya begini" lirik lagu tersebut menunjukan keluh kesah masyarakat yang dibaluti ejekan karena korupsi di negara Indonesia semakin merajalela dan berdampak negatif bagi negara.

Sarkasme

Kata-kata yang digunakan dalam majas sarkasme dapat berupa hinaan yang mengungkapkan rasa marah atau kesal secara kasar, sarkasme digunakan untuk menyinggung dan menyindir seseorang secara langsung, salah satu contoh lirik lagudalam album Frekuensi Perangkap Tikus Volume Dua ditandai kalimat"Hei tuan? bajingan terpelajar" lirik lagu tersebut menunjukan rasa marah masyarakat yang dibaluti hinaan karena banyak orang terpelajar justru tergoda untuk melakukan tindakan korupsi.

Dengan demikian data yang mengandung gaya bahasa sindiran pada lirik lagu dalam album Frekuensi Perangkap Tikus Volume Dua sebanyak 52 data kutipan, yaitu 4 data kutipan sindiran ironi, 37 data sindiran sinisme, dan 11 data kutipan sindiran sarkasme.

\section{E. Implikasi}

Pengajaran sastra secara langsung atau tidak akan membantu siswa dalam mengembangkan wawasan terhadap tradisi dalam kehidupan manusia, menambah kepekaan terhadap berbagai problema masyarakat, serta menambah pengetahuan siswa terhadap berbagai konsep teknologi.

Saat ini kurikulum yang digunakan dalam dunia pendidikan sekarang adalah kurikulum 2013 merupakan pembelajaran kompetensi dengan memperkuat proses pembelajaran dan penilaian autentik untuk mencapai kompetensi sikap, pengetahuan dan keterampilan.
Dalam pembelajaran bahasa Indonesia lirik lagu dapat digunakan sebagain bahan ajar dalam proses pembelajaran, karena lirik lagu memiliki keterkaitan dengan pembelajaran bahasa dan sastra indonesia di sekolah, lirik lagu juga memberikan pembelajaran tersendiri bagi peserta didik yang mendengarkan dan membaca lirik lagunya karena banyak mengandung nilai-nilai sosial seperti halnya masalah sosial akibat faktor ekonomi, budaya, biologis dan juga psikologis dan sebagainya.

Lirik lagu dalam album Frekuensi Perangkap Tikus Volume Dua banyak dikenal dikalangan manapun, lirik album lagu tersebut mengangkat isu korupsi yang terjadi di Indonesia, lirik album lagu membuat karyanya banyak disukai. Pesan yang disampaikan pada liriknya mudah untuk dinikmati dan secara realita terjadi di dalam kehidupan masyarakat.

Berdasarkan dangan kurikulum 2013, Kompetensi Dasar (KD) pada kelas $\mathrm{X}$ dalam materi apresiasi puisi sehingga Guru memiliki inovasi baru dalam proses pembelajaran serta memiliki bahan ajar sebagai pendamping buku paket. Penelitian tentang gaya bahasa sindiran dapat dikembangkan sebagai bahan ajar sastra di SMA sesuai dengan silabus Kurikulum 2013 pada kelas X semester dua. Kompetensi Dasar (KD) tersebut, yaitu: 3.17 menganalisis unsur pembangun puisi.

Seperti yang dipaparkan di atas bahwa lirik lagu sangat membantu proses pembelajaran Bahasa Indonesia di sekolah khususnya di SMA maka dari itu gaya bahasa sindiran dalam lirik lagu dapat diimplikasikan terhadap pembelajaran Bahasa Indonesia di SMA.

\section{SIMPULAN DAN SARAN}

Kumpulan lirik lagu dalam album Frekuensi Perangkap Tikus Volume Dua mengandung gaya bahasa sindiran jenis ironi, sinisme, dan sarkasme. Berdasarkan hasil analisis gaya bahasa sindiran dalam album Frekuensi Perangkap Tikus Volume Dua terdapat 52 kutipan lirik lagu yang mengandung gaya bahasa sindiran.

Album Frekuensi Perangkap Tikus Volume Dua ini, dapat dijadikan bahan pembelajaran Bahasa Indoenesia bagi siswa di SMA karena adanya penggunaan gaya bahasa sindiran, selain itu dapat mengasah kepekaan terhadap sekitar, peduli terhadap sesama, dan mencegah terjadinya korupsi. Dengan demikian, penelitian ini layak untuk dijadikan pembelajaran dalam studi Bahasa Indonesia di SMA.

\section{REFERENSI}

Awe, Mako. 2003. Fals Nyanyian di Tengah Kegelapan. Yogyakarta: Ombak.

Cahyo, Ahmad Nur, dkk. 2020. "Analisis Penggunaan Gaya Bahasa Sarkasme Pada Lagu Bahaya Komunisme Karangan Jason Ranti”. Jurnal Sastra. Volume 9 No. 1.

Gustina, Maya. 2018. Esiklopedia Bahasa dan Sastra Indonesia Gaya Bahasa. Klaten: PT. Intan Prawira.

Hermintoyo, M. 2014. Kode Bahasa dan Sastra: Kalimat Metaforis Lirik Lagu Populer. Gigih Pustaka Mandiri. 
Keraf, Gorys. 2009. Diksi dan Gaya Bahasa. Cetakan 19. Jakarta: Gramedia Pustaka Utama

Moleong, Lexy J. 2007. Metodologi Penelitian Kualitatif. Bandung: PT Remaja Rosdakarya.

Nurdin, A. Dkk. 2004. Intisari Bahasa dan Sastra Indonesia untuk SMU. Bandung: CV Pustaka Setia.

Pradopo, Rachmat Djoko. 2009. Pengakajian Puisi. Yogyakarya: Gadjah mada University Press.

Rachmadani, Dwi Febriyani. 2017. "Analisis Penggunaan Gaya Bahasa Pada Puisi Karya Siswa SMA Di Yogyakarta". Yogyakarta: Universitas Negeri Yogyakarta.

Rani. 2018. "Penggunaan Majas Sindiran dalam Pembelajaran Bahasa Indonesia Siswa Kelas IX SMP Negeri 1 Balaesang Desa Tambu Kecamatan Balaesang Kabupaten Donggala". Jurnal Bahasa dan Sastra. Volume 3 No. 4.

Resdiansyah, Rezza. 2019. "Pemaknaan Lirik Lagu Yoshiwara Lament Karya Asa”. Bandung: Universitas Komputer Indonesia Bandung.

Setiyaningsih, Ika. 2019. Gaya Bahasa dan Aplikasinya. Yogyakarya: PT Penerbit Intan Mutiara.

Suhanto. 2020. "Gaya Bahasa Hiperbola dan Ironi Lagu-lagu Slank Dalam Album Generasi Biru dan Implikasinya Terhadap Pembelajaran di SMA”. Tegal: Universitas Pancasakti Tegal.

Tarigan, Henry Guntur. 2013. Pengajaran Gaya Bahasa. Bandung: CV. Angkasa.

Triningsih, Diah Erna. 2018. Gaya Bahasa dan Peribahasa dalam Bahasa Indonesia. Klaten: PT Intan Pariwara.

Waluyo, Herman J. 2002. Apresiasi Puisi: Gramedia Pustaka Utama. 